\title{
Reformatoriese toetrede tot die derde golf van bydraes oor die Triniteit
}

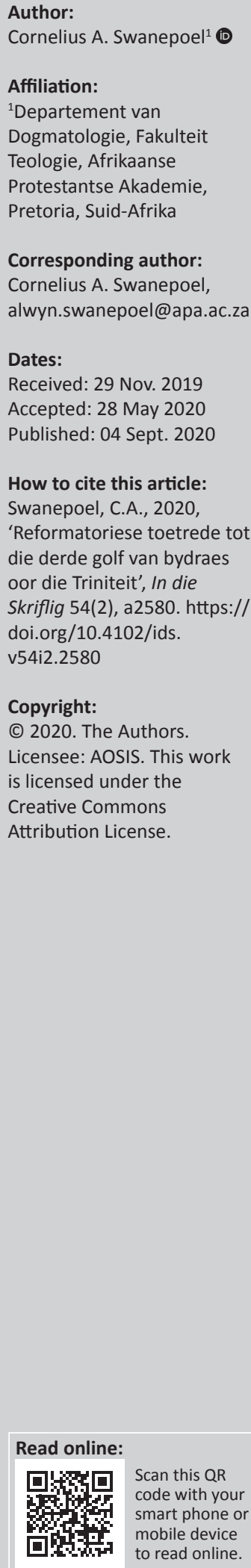

\begin{abstract}
A reformational entry into the third wave of contributions on the Trinity: There has been a so called renaissance in theological studies on the Trinity in the last century. The basic outlines of many of these contributions have been pointed out as revisionist projects that are very much in line with postmodern critiques of rationality and hierarchy. This study gave an initial response by providing leading names who are critical of the revisionist proposals and who are doing important work in various areas regarding the Trinity. Some points of contention between the classical view and the personalist view of the Trinity have been pointed out in the process. These critical contributions show the importance and vibrancy of a third wave of publications on the Trinity and they advocate for a deeper appreciation of ressourcement theology. In line with these retrievement projects, two reformed theologians' recent work have been summarised in order to give an idea of the stimulating contributions that can come from the reformed base and the classical view in conversation with the personalist view. Some suggestions have also been given at the end on important aspects such as the simplicity of God that need further investigation. Some possible political implications of the classical view have also been pointed out. This whole discussion could contribute to a more definite debate on methodology and metaphysical considerations as well as the role of correlation theology in the so called personalist and social approaches to the doctrine of the Trinity. It could also provide new energy for a resurgence of ressourcement theology and retrievement projects regarding the doctrine of the Trinity among theologians in the reformed tradition in South Africa.
\end{abstract}

Keywords: Retrievement theology; Correlation theology; Classical theism; Resourcement; Retrievement; Simplicity; Impassibility; Trinitarian.

\section{Inleiding}

Die gereformeerde teologie behoort in die leer van die Triniteit vandag ten minste twee uitdagings te hanteer. Die meer algemene uitdaging gaan daaroor dat gerekende reformerende teoloë soos Robert Letham (2004:5-6) daarop kan wys dat die meeste Westerse Christene praktiese modaliste is. Letham (2004:5-6) haal ook vir Colin Gunton aan wat beweer dat die neiging tot modalisme aan die wortel van die ateïsme en agnostisisme lê wat die Westerse kerk konfronteer. Intussen was daar 'n sogenaamde Trinitariese renaissance, ook genoem oplewing (vgl. Vanhoozer 2014:31), wat in die twintigste eeu plaasgevind het en bepaalde antwoorde hierop begin gee het. Dit het daartoe gelei dat iemand soos Stanley Grenz (2004:1-5) die bydraes rondom die leer van die Drie-eenheid kon beskou as waarskynlik van die verreikendste vir die teologie in hierdie tydperk. Dit bring reeds die tweede uitdaging na vore wat in besondere sin op ons tyd gerig is. Wat is gereformeerdes se bydrae vandag in hierdie verband? Venter (2011:6-7) wys byvoorbeeld aan die hand van Van den Brink en Van Erp daarop dat daar, met uitsondering van Noordmans, 'n opvallende afwesigheid van produksie oor die Triniteit in Nederland in die twintigste en een-en-twintigste eeu was. Intussen het die produksie in Suid Afrika nie agterweë gebly nie, en Ernst Conradie (2019) het onlangs 'n handige oorsig oor geleerde bydraes oor die Triniteit in Suid-Afrika gegee.

Hierdie artikel tree die beweging tegemoet deur eerstens kenmerkende aksente in die oplewing te beskryf. Daarna word voorlopige kritiese opmerkings gemaak. In die volgende afdeling word daar opsommend na twee reformatoriese teoloë gekyk wat vanuit die tradisie vernuwende antwoorde op die uitdagings begin ontwikkel het. Ten slotte word 'n paar gevolgtrekkings asook enkele voorstelle gemaak vir verdere ondersoek. 


\section{Kenmerkende aksente van die oplewing: Venter se beskrywing}

Vir 'n gedetailleerde bespreking van die oplewing in bydraes oor die Triniteit, kan die werke van Letham (2004), Grenz (2004) en Kärkkäinen (2007) geraadpleeg word. Hier word gebruik gemaak van die opsommende werk van Rian Venter (2011) se intreerede by die Universiteit van die Vrystaat. Venter sit die belangrikste kenmerke van die oplewing handig uiteen en maak die opspraakwekkende stelling dat die ontevredenheid met die klassieke teïsme wyd aanwesig is. Dit gaan hierin veral oor die Hellenistiese oriëntasie, die monargiese en hiërargiese strukturering, asook die gebrek aan patos (impassiblity) wat volgens Venter (2011), in die klassieke weergawes van die Triniteit na vore tree. Venter stel dat dit vir 'n beduidende aantal geleerdes onhoudbaar geword het - intellektueel, maar ook Bybels gesproke. Hy stel verder dat die verskuiwing in denkwyses vanaf substansialistiese na relasionele metafisika, 'n diepgaande invloed op die Christelike Godsleer het.

Vervolgens gee Venter (2011:4-5) dan vyf waardevolle punte van interaksie wanneer hy die belangrikste beklemtonings van die oplewing in die trinitariese teologie identifiseer. Eerste op sy lys is 'n ekumeniese begeerte om geloof in die Drie-eenheid as die hart van die geloof te rehabiliteer. Later verwys hy na Barth as voorbeeld en verduidelik dat ons hier met ' $n$ verstaansraamwerk te make het waaruit die hele teologie benader behoort te word.

Venter se tweede en derde punte van interaksie sluit eintlik baie nou by mekaar aan. Die beklemtoning wat hy in die herlewing van die teologie oor die Triniteit vind, het te make met die doelbewuste hersentrering wat rondom die ekonomie van verlossing in die lewe, sterwe en opstanding van Christus plaasgevind het. Dit beteken dat die verlossingsekonomie die grondslag van alle kennis van God is. Dit gaan daaroor dat die identiteit van God in die Christelike gesprek nie los van of agterom die konkrete heilsdade van Christus en die Gees in die geskiedenis benader behoort te word nie en alle spekulasie so ver moontlik vermy moet word. Dit sluit aan by sy derde punt en het te make met Karl Rahner se bekende 'reël' dat die ekonomiese Drie-eenheid inderdaad die immanente Drie-eenheid is en mutatis mutandis dat die immanente Drie-eenheid ook die ekonomiese Drie-eenheid is. Volgens Venter (2011) is dit 'n definiërende vraag wat die res van die debat fundamenteel beïnvloed.

Venter se vierde punt hou veral met die genoemde metafisiese Verskuiwing verband wat van substansie na relasie plaasgevind het. Met verwysing na die werk van die Oosters-Ortodokse teoloog, John Zizioulas, neem Venter sy werk as voorbeeld van 'n nuwe relasionele ontologie. Die Godheid word op hierdie wyse baie sterker waardeer in terme van persoonskap, verhouding, die ander, en gemeenskap. Ook by Moltmann bespeur Venter dieselfde relasionele fokus op persoon, relasie en perigorese, waar die perigoretiese konsep van persoon as ' $n$ verbetering op 'n blote kommunitariese begrip voorgehou word. Venter vind veral die begrip 'ruimte' (space) by Moltmann boeiend in sy latere geskrifte waar elke persoon 'n leefruimte vir die ander is en het dit dan ook elders kreatief en boeiend op stedelike ruimtes toegepas (vgl. Venter 2006). Vir Venter is hierdie sosiale begrip van die Drie-eenheid niks anders nie as ' $n$ eksegese van die Johannese belydenis dat God liefde is. Dit maak volgens hom deel uit van die grammatika van persoonskap, verhouding, gemeenskap en wederkerigheid.

Venter (2011:6) maak dan hieroor 'n verdere insiggewende stelling, naamlik dat die wending na verhoudings meestal ook met ' $n$ draai na patos gepaard gegaan het. Dit beteken, sê Venter, dat die logika van liefde dit onmoontlik maak om nie aangeraak te wees nie. Die terme waarmee hy God en gemeenskap wil beskryf is treffend: vrugbaarheid, begiftiging, 'ek-stasis', ruimte-maak, gasvryheid, vrygewigheid, en patos. Dit klink indrukwekkend en gereformeerde teoloë wat aan die besinnings oor die Triniteit wil deelneem, sal deeglik hieroor rekenskap moet gee.

Venter se vyfde punt het met wyle Catherine LaCugna (19521997) se programmatiese stelling te make, naamlik dat die leer van die Drie-eenheid uiteindelik ' $n$ praktiese leerstelling is met radikale gevolge vir die Christelike lewe. Verwysend na die feesbundel aan Moltmann in 2006 as voorbeeld, stel Venter (2011) dit soos volg:

$[T]$ he doctrine of the Trinity is a 'heuristic framework' ... or a 'regulative framework' ... for thinking about God, the world, history and humanity. This conviction, shared among a vast array of theologians across the ecumenical spectrum, has become the stimulus for revisioning almost all doctrines and contemporary challenges. Trinitarian anthropologies and ecclesiologies are found; proposals proliferate for thinking Trinitarianly on the problem of the one and the many, social life, gender relations and world religions. (p. 6)

Venter (2011:6) se laaste toepassings oor geslagtelikheid en wêreldgodsdienste laat egter ook die vraag ontstaan, naamlik watter vaarwaters hiermee betree word en of daar moontlik te krities met die verlede en te kritiekloos met die hede omgegaan word. Die rede is dat Venter se beskrywings en toepassings duidelik in die tradisie van ' $n$ omvattende hersiening ('revisioning almost all doctrines') staan. Agt jaar later gee Venter (2019) wel blyke daarvan dat die beskouing oor hersiening deur kritiese stemme getemper is wat ten gunste van die tradisie opgeklink het, maar in wese word daar steeds sterk aansluiting by 'n relasionele herbeskrywing gevind. Daar is ook ander teoloë in SuidAfrika wat werklik moeite gedoen het die afgelope tyd om vernuwende bydraes te bied oor die Triniteit. Conradie (2019) se bydrae en onlangse oorsig oor Suid-Afrikaanse bronne is in hierdie opsig van groot waarde. By die herdenking van 'n 150-jarige bestaansjaar van 'n reformatoriese instelling is dit egter gepas om kritiese vrae te vra oor die aard en graad van revisionisme en oor die wyse waarop daar in die nuwe bydraes met die tradisie omgegaan word. 


\section{Kritiese opmerkings oor die oplewing}

Bogenoemde voorstelle tot hersiening en herbeskrywing moet eers duidelik kan aantoon dat die neigings van die dag nie maar net ingelees en teruggelees word in die teologie nie. Dit roep natuurlik reeds die hele onderskeid tussen korrelasie-teologie en herwinningsteologie na vore. Korrelasie-teologie is volgens die reformatoriese filosoof, J.K.A. Smith (2004:35), daarop ingestel om 'n proses tussen teks en konteks te bemiddel, maar op so 'n wyse dat 'n neutrale ruimte van kennis tussen teks en konteks dikwels onkrities veronderstel word en waarin daar te maklik naïef in filosofiese en politieke water van die dag geswem word. Die teologie word op hierdie wyse net bolangs met die konteks gekorreleer en, bewus of onbewus, selfs in terme van die raamwerke daarvan uitgedruk (vgl. ook Strauss 2002). J.K.A.Smith verwys spesifiek na Milbank as verteenwoordiger van 'n post-sekulêre teologie wat hierdie benadering grondig bevraagteken. Milbank ([1990] 2006:208) wys in hierdie verband daarop dat formele ortodoksie in 'n korrelasiebenadering dalk nog in naam aanvaar word, maar dat dit eintlik maar neig om 'n dowwe glos op regulerende Kantiaanse etiek te wees met ' $n$ ietwat eklektiese, dog basies Marxistiese sosiale teorie in die onderbou daarvan. Dit is ook die leemte in Conradie (2019) se onlangse voorraadopname en beoordeling van geleerde bydraes insake die Triniteit in Suid-Afrika. Conradie gee in sy artikel uiteindelik' $n$ treffende skema van hoe om sin te maak van die ontologiese en ekonomiese Drie-eenheid en die toepassings wat daaruit spruit. Sy oogmerk is om sodoende aan te toon hoe die sogenaamde renaissance in trinitariese denke nog steeds nie genoegsame antwoorde hiervoor bied nie. Conradie doen dit op stimulerende wyse vanuit ' $n$ belangrike bydrae van die bekende reformatoriese teoloog, Arnold van Ruler, maar sy opmerkings aan die einde stem nie heeltemal ooreen met die skynbare pluralisme en perspektivisme waarmee hy begin en wat hy blykbaar met sy treffende einde wil versoen nie. Hierdie spanning tussen die begin en einde van sy betoog kan teruggevoer word na die feit dat hy nie die basiese onderskeiding tussen ' $n$ teologie van korrelasie en herwinning op gepaste wyse aan die orde stel nie. Conradie toon tekens daarvan dat hy, soos N.P. van Wyk Louw (1986) dit binne ander konteks gestel het, vanuit die tradisie teologie wil beoefen, en sy sterk appèl op Van Ruler om sy saak te begrond wys in hierdie rigting. ${ }^{1}$ Die begin van sy artikel laat blyk egter dat Conradie (2019) se opmerkings steeds gekompromitteer bly deur korrelasie-aannames en daarom is sy beklaging dat daar ' $n$ gebrek aan konsensus is, in werklikheid ironies. Dit is egter presies die genoemde onderskeid tussen herwinningsteologie en korrelasieteologie wat sy treffende voorspraak sou steun en groter stu-krag daaraan sou kon verleen. Dit is ook hierdie aksent wat vir lank eie was aan die Potchefstroomse opleiding en wat belangrik is om mee te neem in die toekoms.

Om een verdere voorbeeld van korrelasie-tendense te gee: Venter (2010:571) verwys in sy indrukwekkende navorsing

1.Louw (1986:433e.v.) het treffend gestel dat ons nie bloot los van die tradisie of in die tradisie moet werksaam wees nie, maar eerder vanuit die tradisie. Vir 'n lys van tradisie moet werksaam wees nie, maar eerder vanuit die tradisie. Vir ' $n$ lys van
publikasies oor die onderwerp van herwinning (retrievement/retrieval) kan Peterson (2016:4, voetnoot 3) geraadpleeg word. byvoorbeeld onkrities na 'n treffende stelling van Polkinghorne wat stel dat die Triniteit beskou behoort te word as 'a true Theory of Everything'. Hy beweer dat dit waarskynlik 'n poging is om die praktiese aard van die leerstelling te rehabiliteer en om die publieke relevansie van geloof in God te bevestig. Vergelyk egter in hierdie verband Alcade (2019:loc. 1088-1094 van 6488) se onlangse kritiek op Polkinghorne. Alcade is van mening dat Polkinghorne met ' $n$ matige vorm van ekstrinsesisme (veruitwendiging of eksternalisme) in sy benadering werk en dat dit daartoe lei dat hy van meet af aan gemotiveer word deur opvattings van neutrale feite en metodologie waarin daar nie deurgaans met die wetenskap - in samehang met die teologie en die metafisika - rekening gehou word nie: 'Because science, metaphysics, and theology are inherently related, this mild extrinsicism is ultimately untenable.' Opvattings van die Triniteit kan dus maklik gebruik word om die eeue-oue vraag na die verband van eenheid en veelheid onder woorde te bring, maar steeds meer in verband staan met bolangse en tendensieuse integrasie en projeksie.

Die reformatoriese filosoof, Danie Strauss (1991:39-41), het in hierdie verband reeds lankal die gevaar van'n tipe teo-ontologie aangetoon wat filosofiese konsepte in die Triniteit inlees en van daar weer teruglees in die werklikheid. Hiervan moet deeglik rekenskap gegee word. Hierdie artikel tree nie in diepte met hierdie filosofiese veronderstellings in gesprek nie, maar hou wel rekening met die moontlikheid van hierdie tipe projeksie, ook in eie arbeid. Dit gee wel'n eerste paar treë waar vernuwing eerder vanuit die tradisie benader word, terwyl die funksie van filosofiese en politieke metatekste in gedagte gehou word. Hier word daarom saam met Allen en Swain (2015) van die standpunt uitgegaan dat die benadering van herwinning en vernuwing vanuit die tradisie gewoon net 'n beter natuurlike ruimte vir die gereformeerd-katolieke tradisie is. Daar word ook by die handige kartering van J.K.A. Smith (2204:34-35) aangesluit wat 'n duidelike alternatiewe weg vir die reformatoriese teologie eien as dié van korrelasie-teologie. Dit beteken nie dat die reformatoriese teologie nie baie medestanders en medestryders hieroor uit ander tradisies kan vind nie (vgl. Allen \& Swain 2015: 1-16; 155-162). Dit beteken wel dat die reformatoriese teologie ook nou prinsipieel oor vernuwing vanuit die tradisie standpunt behoort in te neem.

Indien hierdie feesvierings getrou wil wees aan die afgelope 150 jaar, terwyl daar ook op die skouers hiervan dankbaar, krities en vernuwend voortgebou word, sal dit nie anders kan as om hieroor die basuin duidelik te laat hoor nie. Sterker gestel, indien hierdie feesvierings meer wil wees as die laaste stuiptrekkings van 'n ou orde wat dalk gedeeltelik goed was, maar nou eintlik verby is, behoort die onderskeid tussen die gereformeerd-katolieke tradisie en die tradisie van korrelasieteologie as wesenlik geag te word.

As voorbeeld van hoe belangrik hierdie saak van vernuwing vanuit die tradisie is, wat natuurlik heeltemal iets anders as repristinasie impliseer, kan die belangrike werk van Stephen Holmes (2012) as voorbeeld geneem word. Holmes beskou 
die hedendaagse hersieningspogings oor die Drie-eenheid as onoortuigend. Volgens Holmes wyk baie briljante hersienings wat gepubliseer is metodologies en materieel af van die ouer tradisie en moet daarom as afwykings eerder as oplewings daarvan getipeer word. Hy kan selfs stel dat die tradisionele leerstuk van die Triniteit so misverstaan en verdraai word dat dit onherkenbaar is. Venter (2012) antwoord weliswaar indringend op ' $n$ artikel van Holmes van 2009, maar die meer uitgebreide besinning van Holmes se publikasie van 2012 word, sover vasgestel kon word, nog nie afdoende beantwoord nie. Venter oortuig verder ook nie dat hy Holmes se kritiek op uiteenlopende gevolgtrekkings uit die oplewing van trinitariese denke bevredigend beantwoord nie. Die moontlikheid van onversoenbare uitgangspunte in die ekklesiologieë van Zizioulas en Moltmann, kan byvoorbeeld nie noodwendig bloot as variasie en verskeidenheid van interpretasiemoontlikhede afgemaak word nie. Dit kan ook die vermoede versterk dat die kritiek van bolangse versoening, asook die kritiek van eksternalisme soos deur Alcade hierbo verwoord, verder ondersoek behoort te word.

In hierdie verband bied iemand soos Derrick Peterson (2013) se belangrike resensie van Holmes se werk ook verdere perspektief. Peterson maak aan die hand van Sarah Coakley, gerekende spesialis in die teologie van die Kappadosiërs, melding daarvan dat daar inderdaad reeds van 'n tipe derde golf sprake is wat baie elemente van die trinitariese oplewing grondig bevraagteken. Peterson (2013:102-108) noem in verband met die herwinnende herlees van Augustinus die name van Lewis Ayres, Michel René Barnes, Michael Hanby ${ }^{2}$ en Rowan Williams. Hy noem die name van Gilles Emery, Matthew Levering, Jean-Pierre Torrell en Karen Kilby in verband met die herwinnende herlees van Thomas Aquinas. Die name van John Milbank en Catherine Pickstock (2002) sou natuurlik hierby gevoeg kon word. Peterson noem ook die name van Thomas Weinandy, Paul Gavrilyuk, Daniel Costello en David Bentley Hart in verband met 'n postmetafisiese interpretasie wat op kritiek oor die gebrek aan patos in sommige ouer weergawes van die Triniteit reageer. Peterson gaan selfs sover om te beweer dat daar baie seker gemaak moet word dat die 'okkulte' van die moderne teologie nie die dwaalleer in die kerkgeskiedenis vir die twintigste en een-en-twintigste eeu verteenwoordig nie. Hy wys ook op die woorde van Walter Kasper (vgl. 2012:264) wat gestel het dat die geskiedenis van die moderne denke, vanuit 'n bepaalde hoek beskou, eintlik maar die geskiedenis is van die baie pogings om die leer van die Triniteit te herdefinieer. Hierdie oortuigings van Peterson word verder gevoer in 'n ander artikel waar hy (Peterson 2016:3-36) aanvoer dat die sogenaamde renaissance in trinitariese denke grootliks saamhang met teenreaksie op ' $n$ historiese vertekening van trinitariese denke wat mettertyd posgevat het.

Daar is dus baie om te delf en te sif, te oorweeg en te beoordeel, te verbeel en te doen, vir die reformatoriese teologie van die een-en-twintigste eeu. Om die waarheid te

2. Hoewel ek nie naastenby by al hierdie name kon uitkom nie, het ek wel op Hanby (2003) se werk oor Augustinus ingegaan. Hanby se werk is diepsinnig en uiter belangrik vir diegene wat Augustinus teologies wil begryp. sê, dit is 'n vraag of daar nie 'n hele groep reformatoriese teoloë nodig is om hierdie werk voortreflik te doen nie. Dit sal egter teoloë moet wees wat die bydrae van Potchefstroom se stem oor die jare heen as belangrik ag en daarom ook prinsipieel standpunt téén die korrelasie-teologie en die slegte vorms van postmoderne teologie kan inneem. Hierdie teoloë behoort dit hierteenoor op te neem vír konstruktiewe post-sekulêre teologie en reformatoriese vernuwing vanuit die tradisie sonder om onkrities oor die verlede te wees of in repristinasie te verval. Deeglike en geloofsgehoorsame Skrifkennis, 'n skerp oog vir outentieke analogie, 'n sensitiewe oor vir gees en bedoeling en nuanse in kerk sowel as dogmengeskiedenis, fyn aanvoelings vir filosofiese roerings, en doksologiese harte wat dors na die geregtigheid is nodig om die misterieuse Triniteit op gepaste wyse te benader. Dit is wel reeds bemoedigend om te verneem van 'n derde golf besinnings oor die Triniteit wat in swang is en wat bereid is om herwinnend te hersien, ook wanneer dit nodig is om die hersienings te hersien. ${ }^{3}$ Post-sekulêre teologie wat respekvol en krities kan luister na die verlede asook na die hede, het eenvoudig die roeping om na te gaan of hedendaagse dekonstruerings nie ook gedekonstrueer moet word nie.

So 'n projek vereis duidelik 'n omvattende benadering en hier kan slegs gepoog word om inleidende indrukke van die tipe herwinning en kreatiewe vernuwing vanuit die tradisie te gee wat op hierdie weg moontlik is en wat die stem van Potchefstroom vir 'n volgende era voortreflik sou kon uitbou. Vir hierdie doel word hier inleidend op twee name uit die reformatoriese tradisie waarmee ek bekend is gefokus, en wat in die nuwe eeu beduidend en stimulerend oor genoemde onderwerp gepubliseer het. ${ }^{4}$

\section{Reformatoriese toetrede tot die oplewing Die bydrae van Ralph A. Smith}

Ralph Smith is 'n leraar van Mitaka Evangelical Church in Tokyo in Japan. Hy het in drie publikasies (2002; 2003; 2004) gepoog om vernuwing in die waardering van die Drie-eenheid en die verbond aan te moedig. Smith (2002:105) is van mening dat ' $n$ herlewing van belangstelling in die leer van die Drieeenheid onder reformatoriese teoloë eintlik moes plaasgevind het lank voor dit in die liberale teologie gebeur het, maar dat dit ongelukkig nie die geval was nie. Smith wys egter ook daarop dat daar darem nie niks gebeur het nie. Hy beskou byvoorbeeld spesifiek Abraham Kuyper en Cornelius van Til se bydraes as vol potensiaal om beduidende uitbouings van die leer van die Drie-eenheid daar te stel. Smith het probeer om in sy drie publikasies verder op hierdie twee teoloë se insigte voort te bou.

3.Die konferensie oor trinitariese ontologiee wat gehou is in Cambridge vanaf $13-15$ September 2019, met 'n bundel wat waarskynlik sal verskyn, behoort ook enigsins ' $n$ idee te gee van wat tans vaardig is.

4.Daar is natuurlik ook ander persone wat reeds stewige implikasies uitgebring het waarby die reformatoriese teologie wansluiting kan vind, soos byvoorbeeld Robert Letham (2004) en Fred Sanders $(2004,2010,2016)$. Sanders se belangrike kritiek op Rahner se genoemde reël is belangrik om na te gaan en sy onlangse werk oor Rahner se genoemde reël is belangrik om na te gaan en sy onlangse werk oor
ortodokse Trinitariese denke vanuit die Skrif wat rekening hou met die resente ortodokse Trinitariese denke vanuit die Skrif wat rekening hou met die resent
navorsing, is een van die standaardwerke vir reformatoriese teoloë vandag. 
Smith se vertrekpunt in sy denke oor die Drie-eenheid is die werk van Cornelius van Til. Hy is verbaas oor die verwaarlosing van hierdie gereformeerde teoloog se werk oor die Drie-eenheid. Smith (2002) gee die rede vir sy eie waardering en dit stem eintlik baie ooreen met die eerste oogmerk wat Venter genoem het:

[W] hat could be more significant than a view of the Trinity which places the doctrine not only in the centre of the entire theological enterprise, but also every academic and practical discipline, a view of the Trinity which sets forth the triune God as the very heart of the entire Christian worldview? (p. 15)

Smith (2002:55) wys ook verder daarop dat hy via Van Til die leerstelling van die Drie-eenheid as die uiteindelike antwoord op die probleem van eenheid en veelheid beskou, in die sin dat nóg die veelheid, nóg die eenheid voorkeur in tyd of logika bo die ander geniet. Volgens Van Til moet die eenheid en die veelheid van God gelyktydig as volkome realiteit geld. Hierdie Van Tilliaanse toepassing vanuit die Drie-eenheid is 'n belangrike aspek van Smith se teologie. Hy glo egter dat daar 'n belangrike sin is waarin Van Til se leer nie konkreet genoeg was nie, hoewel hy dit as implisiet in Van Til se benadering beskou. Smith (2002:72) is oortuig dat dit eksplisiet gemaak moet word om sodoende die verband tussen die leerstellings van God, die skepping, die openbaring, die mens en die verlossing duidelik te maak. Die ontbrekende skakel volgens Smith (2002:73), is die leer dat die Persone van die Drie-eenheid ewig in 'n verbondsgemeenskap van liefde verenig is. Volgens Smith (2002:73) bied dit die moontlikheid van 'n wêreldbeskouing waarin die leer van God die fontein is waaruit alle ander waarhede vloei. Dit beteken dan dat die verbondsgemeenskap van die Drie-eenheid die ideale gemeenskap is. Basiese wêreldbeskoulike temas soos wêreld, persoon, taal, liefde, vryheid en wet, sê Smith (2002:73), word in die persoonlike verbondsgemeenskap van Vader, Seun en Gees geïntegreer en verenig.

Smith (2003) bou in een van sy kernbeklemtonings voort op Geerhardus Vos se opmerking dat die verbond van verlossing die hoogtepunt van die gereformeerde teologie is, maar hy gebruik die werk van Herman Hoeksema en Abraham Kuyper om hierdie stelling te kritiseer en te verdiep. Volgens Smith (2003:45) styg die gereformeerde teologie op sy teologiese hoogtepunt, soos uiteengesit deur sy beste eksponente, nie hoër as soteriologie nie. Om 'n beter benadering voor te stel, maak Smith van die insigte van Kuyper en Hoeksema op die volgende manier gebruik: hy het via Hoeksema op die stelling van Kuyper afgekom dat die pactum salutis ' $n$ nog dieper werklikheid suggereer - die trinitariese verbond in die lewe van die Drie-eenheid self as die ware prototipe van elke verbond. So is die hoogtepunt van die teologie meer as net soteriologie. Smith (2003) sê dan ook waarom dit belangrik is dat die trinitariese verbond in die Drie-eenheid as die hoogste beskou behoort te word - 'n opmerking wat die potensiaal het om 'n groot aansluitingspunt te wees by die oplewende gesprek oor trinitariese teologie:
[T] he Bible has a lot to say about love that is relevant to our conception of God and the communion of friendship that characterizes the Trinitarian life. The self-denial, humility, seeking of the honour and the glory of the other, commitment and works that characterize biblical love are only some of the important aspects of the covenantal fellowship of Father, Son and Spirit. Indeed it is only when we understand that almost wherever the Bible speaks of love, it speaks of covenant, that we can begin to understand what it means to say that God is love. (p. 46)

Op hierdie wyse is dit vir Smith (2003:47) moontlik om te sê dat omdat die verbond nou die doel is, dit ook die middel moet wees wat daartoe lei. Smith se gevolgtrekking is dus dat God drie Persone is wat in verbondsliefde verenig is. Daarom is Smith (2003:49) van mening dat die verbondsidee in die gereformeerde teologie hersien moet word aan die hand van Kuyperiaanse lyne. Hy kontrasteer dit spesifiek met die Skotse Presbiteriaanse tradisie wat die verbond beskou as 'n ooreenkoms tussen die Vader en die Seun oor die verlossing van die uitverkorenes, met die verbond van werke as die primêre een. Smith wil hê dat die trinitariese verbond eerder die belangrikste moet wees. Dit beteken dat die verbond nie eers in gebruik gestel word om die probleem van die mens se sonde op te los nie. In die verbond, sê Smith (2003:51), is die wet die weg van liefde, en is die liefde regverdig en heilig. Hy wys ook daarop dat daar geen ander soort verbond is wat so gereeld en so passievol gebruik word om die verhouding van God met sy mense te beskryf as die huweliksverbond nie. Indien hierdie verbond bedreig word, sê Smith (2003), word God se jaloesie as 'n uiterste vorm van patos uitgebeeld. Die huwelik is, soos Hosea aantoon (Smith 2003):

$[B]$ oth a relationship of love and also a structured legal commitment ... The contractual aspect of marriage does not detract from its passion, but brings the commitment of love to concrete expression. (p. 49)

Vir die doeleindes van hierdie artikel is dit duidelik dat Smith se bydrae daarin geleë is dat die liefde meevoerend op die voorgrond staan, maar tog steeds op verbondsmatige wyse gestruktureer word en dat liefde en wet hiervolgens nie teenstellings van mekaar is nie. Dit is ook duidelik dat 'n gebrek aan patos nie te bespeur is in hierdie verbondsmatige beskrywing nie. Smith (2003:54) reageer op die bekende argument van Catherine LaCugna dat die Griekse en Latynse benaderings tot teologie twee verskillende visies op persoonwees asook ook op die Christelike lewe en die samelewing bied. Smith (2003) suggereer egter via sy gebruik van Kuyper 'n derde weg, wat 'n duidelike reformatoriese bydrae tot die trinitariese teologie wil wees:

$[A]$ doctrine of God as a God who is 'for us' but who remains sovereign, a God who is the model of personhood and society in a concrete and definable manner, but who remains transcendent, a God of love who is close to us, but who is no less Lord and King. The covenant among the persons of the Trinity is Latin in the sense that it is a doctrine of three coequal persons in fellowship, but, insofar as covenant is a concrete idea and the details of our covenant obligation are spelled out in scripture, it is never 
abstract. Covenant is also as Jordan shows, community life, and man was created to enter that community life. In this sense, the Reformed view is also Greek, 'the communion of all in all, all in God, God in all', but without the confusion that comes from identifying 'in' as expressing an ontological relationship. (p. 54)

Met die laaste sin se 'in' in aanhalingstekens, verwys Smith na 'n beskrywing van LaCugna wat baie aan die panenteïsme herinner en wat in die postmoderne teologie heersend is. Hy kan egter die oomblik van waarheid hierin akkommodeer, maar ook die struktuur bied om te verseker dat dit verbondsmatig benader en waardeer word. Dit is baie betekenisvol dat Smith $(2002: 73$; 2003:46) woorde soos die volgende kan gebruik wat juis vanuit die Drie-eenheid geïntegreer word: persoon, taal, liefde, vryheid, wet, vriendskap, selfverloëning, nederigheid, op soek na die eer en glorie van die ander, en toewyding en werke wat die bybelse liefde kenmerk. Dit versterk die besef dat die verbondsgemeenskap van Vader, Seun en Gees 'n belangrike rol kan speel in vernuwende denke vanuit die tradisie oor die Triniteit.

\section{Die bydrae van Michael C. Horton}

Soos Smith, bring ook Michael Horton (2006), die bekende gereformeerde professor by Westminster in Escondido, Kalifornië, die idee van 'n verbond in verband met die drieenige God self. In 'n besondere treffende gedeelte toon Horton (2006) aan hoe verlostes deel het aan die verbondsgemeenskap van Vader, Seun en Heilige Gees:

God's very existence is covenantal: Father, Son, and Holy Spirit live in unceasing devotion to each other, reaching outward beyond the Godhead to create a community of creatures serving as a giant analogy of the Godhead's relationship. Created in the image of the Triune God, we are by nature outgoing, interdependent relationship establishers, finding ourselves in the other, not just in ourselves. Unlike the persons of the Trinity, we at one time did not exist. But when God did decide to create, his decree was not that of a lonely monarch, but of a delighted Father, Son, and Holy Spirit establishing a creaturely, finite analogy of their eternal giving and receiving relationship. We were not just created and then given a covenant; we were created as covenant creatures - partners not in deity, to be sure, but in the drama that was about to unfold in history. (p. 10)

Dit is egter ' $n$ leemte dat, in soverre ek kon uitvind, Horton in sy vrugbare skryfarbeid nie spesifiek dieper hierop ingaan nie. ${ }^{5}$ Horton is egter steeds baie waardevol as gevolg van sy kerkgeskiedkundige en apologetiese bydraes aangaande die leer van die Drie-eenheid. Die beste plek om Horton (2011) se trinitariese sienings in oënskou te neem, is waarskynlik sy sistematiese teologie, Christian Faith. Horton (2011) struktureer sy sistematiese teologie in die algemeen volgens die vier treffende oriëntasiepunte van drama, dogma, doksologie en dissipelskap. Dit lei daartoe dat hy ' $n$ onderwerp begin met ' $n$ bybels-teologiese ondersoek, waarna hy fokus op die geskiedenis van die kerkstryde om

5.Horton (2011:273) bring wel hulde aan Douglas Kelly se sistematiese teologie waa hy, volgens Horton, die kwessie van Triniteit en verbond op ' $n$ wonderlike wyse integreer. duidelikheid te kry oor die leer van die Drie-eenheid. So wil hy tot doksologie en dissipelskap vir die huidige tyd kom.

'n Interessante punt in sy bespreking van die Drie-eenheid vir die doeleindes van hierdie artikel, is Horton (2011:288294) se ontleding van Calvyn se bydrae tot trinitariese besinning. Volgens Horton (2011:289), het Calvyn se aandrang dat elke Persoon in die Drie-eenheid ook selfstandig is (autotheos), reeds die weg anderkant die neigings tot subordinasie sowel as modalisme aangewys. Hiervolgens moet ons na Calvyn luister in sy leer van toedeling en van die selfstandigheid van elke Persoon in die Drie-eenheid. Horton (2011) beskou dit as in ooreenstemming met sommige van Zizioulas se beskrywings van die posisie van die Ooste en kan selfs verklaar dat dit identies is aan die Kappadosiërs se konstruksie, soos deur Zizioulas uiteengesit. Horton (2011:292-293) is van mening dat Gunton te ver gegaan het deur te beweer dat Calvyn Augustinus uitdruklik ten gunste van die Ooste verwerp het, maar dink wel dat Calvyn 'n vooruitgang in die Westerse trinitariese teologie verteenwoordig en dat Calvyn wel die rewolusionêre insig van die Kappadosiërs se behandeling van hipostase erken het. Horton (2011:301) meen selfs dat Gunton en Zizioulas gelyk het in hulle klem op persoon as persoon-in-verhouding teenoor ' $n$ idee van persoon as verhouding. Horton se herwinning van Calvyn is dus belangrik vir die gesprek met die trinitariërs buite die gereformeerde tradisie en skep selfs die moontlikheid vir oorweging of daar nie via Calvyn reeds 'n derde weg tussen Oos en Wes moontlik geword het nie.

'n Verdere belangrike bydrae van Horton om van kennis te neem in die evaluering van moderne trinitariese teologie, is die twyfelagtige agtergrond wat hy as die hoofrede vir die oplewing wat plaasgevind het, beskou. Horton (2011:294) noem dat dit Hegel was wat die eerste keer hernude aandag aan die Drie-eenheid gegee het met sy filosofie van 'gees' en geskiedenis en dat hy aansienlik uit Joachim van Fiore se trinitariese historisisme en die radikale panteïstiese mistisisme van Meister Eckart en Jakob Böhme geput het. Horton (2011) stel dit soos volg:

$[H]$ owever it was not so much the historic doctrine itself that interested him, but the use to which it could be put in a speculative ontology of being-as-becoming. Since then, mainline Protestantism, especially since the wake of Karl Barth, has experienced a revival of interest in a Trinitarian theology ... in many respects, contemporary debates in Trinitarian theology reflect the legacy of Barth and Hegel. (p. 294)

Horton (2011:296) gaan voort om Barth en Moltmann as verteenwoordigers te identifiseer van diegene wat die eenheid óf die veelheid voorop stel in die hedendaagse teologie van die Triniteit. In die geval van Moltmann se 'trinitariese panenteïsme' of dan 'sosiale trinitarisme' bemerk Horton 'n Hegeliaanse ontologie. In sy bespreking van die eienskappe van God in sy sistematiese teologie gee Horton (2011:244-253) aandag aan Moltmann se kritiek op die klag van gebrek aan patos in die trinitariese Godsbeskouing van die verlede. Horton (2011:247) se ontleding is skerp: die god 
van die filosowe is net so maklik die projeksie van Heraclitus en Hegel, as van Plato en Plotinus. Hiermee bedoel Horton dat die eensydige beklemtoning van eenheid, maar ook van veelheid, van konstansie, maar ook van dinamika, vanuit filosofiese oogpunt reduksionisme tot gevolg kan hê. Dit geld dus net so sterk vir die teologie wat tans neig om al die klem op veelheid en dinamika te plaas. Horton (2011) poog dan uiteindelik om ' $n$ berekende antwoord te gee op die manier waarop die Bybel ons lei om tussen albei afgronde deur te stuur en rekenskap van die beskuldiging van onaangeraaktheid (impassiblity) in ons Godsbeskouing:

God delights in the work of his hands, in our fellowship with him ... Yet God needs none of this for his own fulfilment ... It is not because God lacks emotion that he loves in freedom, but because he does not lack anything. God does feel, but not as one who depends on the world for his joy. God responds to our sorrows with compassion, to our sin with anger, and to our obedience with delight. Yet he does so as a generous rather than as a needy lover. (pp. 248-249)

Horton (2011:299-303) eindig sy bespreking met riglyne vir besinning. Hy herinner eerstens daaraan dat ons gebruik van die woord persoon steeds analogies van aard is; en tweedens dat 'n nuwe waardering vir Calvyn se beklemtoning van die drie Persone as duidelike selfstandige persone met hulle eie unieke aard, belangrik is. Hy stel dit egter eers pertinent aan die orde nadat hy daarop gewys het dat die Vader, Seun en Heilige Gees nie in hulle Goddelike essensie en eienskappe verskil nie.

\section{Gevolgtrekking en enkele voorstelle}

Smith en Horton bied waardevolle bydraes om die uitdagings in besinning oor die Triniteit tegemoet te tree. Hulle versterk die besef dat konstruktiewe teologie aan die hand van die verbond, sowel as deeglike dogmahistoriese navorsing, tesame met apologetiese sensitiwiteite en oë vir filosofiese denkskemas deur die eeue, baie belangrik is in die benadering tot die misterie van die Drie-eenheid. Dit beteken nie dat Horton en Smith in alle opsigte ooreenstem nie. 'n Verdere ontleding sou ook kon aantoon waar hulle verskilpunte is. Albei deel egter die ooreenkoms dat hulle stimulerende voorbeelde is van hoe vernuwing vanuit die tradisie vandag aangepak sou kon word. Dit is wel insiggewend om raak te sien hoe die verbondsbenadering van Smith met betrekking tot die Drie-eenheid, heelwat van die waarheidsmomente wat in die nuwe hersienings gestel word, gekwalifiseerd sou kon akkommodeer. Die vraag is egter of die nuwe hersienings die sterk Skriftuurlike kwalifikasies en met name die verbondsbenadering van Smith, kan deurstaan. R.A. Smith (vgl. 2004) het ook al heelwat konsekwensies van sy verbondsmatige begrip vanuit die Triniteit uitgewerk. Hy het iets konkreet begin doen in verband met dit wat LaCugna voorgestel het, maar dit terselfdertyd baie sterker vanuit Skrif en tradisie gedoen. Dit is 'n benadering wat ook die werklikheid wil omvorm, maar dan duidelik vanuit die tradisie op trinitaries-verbondsmatige wyse. So kan dit in diens staan van 'n reformatoriese herlewing van die tipe trinitariese teologie waarna Smith (2002:112) verlang.
Dit is hier dan ook gepas om bepaalde voorstelle te maak om die benadering vanuit die tradisie verder te stimuleer. Eerstens moet die grondliggende saak van die simplicitas van God duidelik verreken word, aangesien dit onderliggend aan die debat oor die skynbare gebrek aan patos is. Volgens James Dolezal (2017) is die simplicitas van God wesenlik in die klassieke teïsme. Hy wys daarop dat daar eintlik net twee modelle van Christelike teïsme is wat meeding om die lojaliteit van evangelie-gesinde Christene: Die klassieke Christelike teïsme en die teïstiese mutualisme of personalisme. Laasgenoemde poog om God meer 'persoonlik' voor te stel. Dolezal (2017:14) wys ook daarop dat die Nederlandse Geloofsbelydenis en die Westminster Konfessie vanaf die klassieke verstaan uitgaan. Onder die weergawes van pesonalisme, onderskei hy tussen harder en sagter vorms daarvan. Dolezal is egter van mening dat iets fundamenteel prysgegee word in die pogings om God sogenaamd meer 'persoonlik' vir mense te maak. Volgens Dolezal (2017:loc. 1143 van 6488) is die enkelvoudige wese van God (simplicitas), wat van niks buite Homself afhanklik is nie, die veronderstelde kontrolerende grammatika van al ons spreke oor God. Dit kan daarom nie prysgegee word nie. Wanneer dit wel prysgegee word, sê Dolezal, beteken dit dat God afhanklik is en dat samestellende modelle van eenheid gebruik kan word om te verduidelik hoe God bestaan as drie Persone. Dit beteken dan dat sulke weergawes nie noodwendig monoteïsties is nie, en dat dit ook triteïsties kan wees (Dolezal 2017):

$[W]$ ithout divine simplicity, the Father, Son, and Holy Spirit potentially could be understood either as three parts of God in which case each person would ontologically precede the being of God and each would lack something of the fullness of divinity - or as three discrete beings or gods who collectively make up a social unit we call God. The question facing Christians is not merely whether or not we believe that God is one or if the three persons are a divine unity. Rather, the question is at an even deeper level: What sort of oneness and unity should we ascribe to God? According to Herman Bavinck, 'The oneness of God does not only consist in a unity of singularity ... but also in a unity of simplicity.' (loc. 22792288 van 6488).

Die vraag na watter soort eenheid ter sprake is, bring hiermee ook die vraag na watter soort differensiasie ter sprake is. Julie Canlis (2010:loc. 2685 van 3982) wys in hierdie verband daarop dat trinitariese differensiasie by Calvyn en Irenaeus belangrik is om koinonia reg te waardeer. Die differensiasie beteken dat fusie wel teengestaan word, maar andersyds ook dat differensiasie 'n noodsaaklike deel van egte intimiteit is. Sy (Canlis 2010:loc. 3974 van 3982) trek ook lyne vanuit hierdie verstaan van koinonia na relasionele volheid. Die insiggewende hiervan is dat sy (Canlis 2010:loc. 3967 van 3982) dit opstel teenoor skeefgetrekte weergawes van relasie: 'A "relational anthropology" can be as much a product of the age as have past "rational anthropologies" or "dualistic anthropologies"'. Ook die Rooms Katolieke teoloog en kenner van Barth en T.F. Torrance, Paul Molnar, sluit hom aan by hierdie voorbehoud op relasionele beklemtoning. Molnar (2014) is van mening 
dat die klem op relasie vandag te maklik as 'n ervaring in ons as mense hanteer word wat op die Triniteit terugprojekteer word:

$[T]$ o put it more pointedly, such thinking allows relationality as we experience it to be the starting point for our reflections on the Trinity. It is one of the crucial implications of the classical doctrine of the Trinity that once that occurs, then in reality God becomes the predicate in the sentence instead of the subject and thus becomes whatever we describe using religious and even biblical categories based on the experiences of human relationality that are most important to us. Some obvious examples can be seen in the thinking of representative social trinitarians such as Jürgen Moltmann, Elizabeth Johnson, and Catherine LaCugna. (p. 79-79)

Molnar verduidelik verder dat gemeenskap (communion) in die Triniteit nie sonder meer met die gemeenskap van mense (community) gelykgestel moet word nie. Die klassieke lering van die Triniteit het na sy mening baie sterker vanuit die Woord uitgegaan. Daar is natuurlikaltyd van wederkerigheid sprake, maar dit gaan hier oor die bewustelike uitgangspunt. Dit is ook wat Canlis in die oog het. In haar benadering gaan dit daaroor om die dieptes van koinonia in die Triniteit vanuit Skrif en tradisie te beproef as 'n outentieke antwoord op moderne vervreemding. Canlis (2010:loc. 2695 van 3982) wys op die probleem van vervreemding wat alreeds deur die Eksistensialiste (bv. Sartre, Camus) uitgeken is, deur die Personaliste (bv. Buber, Monier, Levinas) beveg is en deur die Postmoderniste (bv. Foucault, Derrida) omhels is. Die koinonia van God is egter 'n radikale alternatief, sê Canlis. Dit gaan oor gemeenskap en deelname in die lewe van die Triniteit en dit is hier waar sy ook 'n bepaalde soort differensiasie aan die orde stel. Die deelname van die gelowige in Christus beteken vir Canlis nie 'n soort ontlediging waarin die gelowige die eie persoon volledig aflê in die eenwording met Christus nie. Dit beteken eerder dat die gemeenskap in Christus van so ' $n$ aard is dat die eie persoonlikheid enersyds wel tot sonde-aflegging en andersyds ook dat die eie persoon in gemeenskap tot volle wasdom groei. Dit beteken dat die eenheid van die gelowige met Christus nie as veragting van die self hanteer word nie, maar as egte verruiming in Hom (Canlis 2010:loc. 2685 van 3982). Hierdie benaderings tot bepaalde vorms van eenheid en differensiasie in gemeenskap is belangrik en die implikasies daarvan veelseggend wanneer daar na bepaalde toepassings op die politieke terrein gekyk word.

As voorbeeld hiervan kan die gemeenskapsdenker en teologiese filosoof, Danie Goosen (2015), se kritiek op die Belhar-belydenis geneem word. Goosen aanvaar dat die gevolge van apartheid in Suid-Afrika nog lank bespreek en gepeil behoort te word. Hy is egter nie oortuig dat die Belhar belydenis skerp genoeg onderskei tussen apartheid en die andersoortige konteks waarin Afrikaners hulle vandag bevind nie. Daarom word dit volgens Goosen 'ook dikwels deur 'n stemming onderlê ingevolge waarvan die hedendaagse voorspraak vir 'n eie taal- en kultuuridentiteit met 'n voorspraak vir die verlede verwar word.'
Volgens Goosen is daar'n groot verskil tussen die federatiewe antwoorde wat vandag gegee word teenoor die sentralistiese aard van apartheid. Hoewel Goosen nie pertinent stel dat hy vanuit die klassieke opvatting van die Triniteit hieroor dink nie, lê dit beslis in die agtergrond wanneer sy aansluiting by die klassieke teologie en filosofie in ander werke in ag geneem word (vgl. byvoorbeeld Goosen 2007). Dit is daarom insiggewend om te verneem hoe hy (Goosen 2015) die kwessie van gedifferensieerde eenheid aan die orde stel om kritiek op die Belhar belydenis te lewer:

$[A]$ s Belhar met 'eenheid' 'n gedifferensieerde eenheid sou bedoel (dit wil sê 'n eenheid wat die veelheid as noodsaaklik vir 'n gesonde eenheid verstaan) dan sou hy waarskynlik so 'n nuwe benadering vanuit Afrikanergeledere kon ondersteun. Vanweë die sterk aanwesigheid van apartheid in die agtergrond kan Belhar dit waarskynlik nie doen nie. In reaksie op apartheid gee ' $n$ ongedifferensieerde opvatting van eenheid eerder die pas aan. Dit wil sê 'n eenheid wat juis nie klem op die uitbouing van die veelheid van tale en kulture lê nie. Indien bogenoemde inderdaad korrek is, beteken dit dat die onderskeid tussen apartheid en vandag nie skerp genoeg gehandhaaf word nie, en dat Afrikaners aan apartheid vasgeknoop word. (n.p.)

Goosen sou maklik hieroor misverstaan kon word indien daar nie gehoor word dat Belhar se weergawe van eenheid in verskeidenheid nie werklik die veelheid van tale en kulture positief kan uitbou nie. Goosen kritiseer dus 'n opvatting van eenheid waarin daar nie genoegsaam met die positief uitbouende kulturele verskeidenheid van groepe rekening gehou word nie. Uiteindelik is die verskeidenheid waarvan daar in Belhar sprake is (en wat implisiet baie individualisties voorkom),'nskynbaar terloopse ondergeskikte werklikheid wat die indruk gee dat dit tog uiteindelik deur 'n soort fusie sal uitfaseer. ${ }^{6}$ Dit hou daarom nie genoegsaam rekening met opvattings van federale gemeenskapsdenke wat ook kultuurgroepe as deel van die skepping sowel as herskepping waardeer nie. Dit is dan ook juis hierdie federale gemeenskapsopvattings wat groot aansluiting by die vorms van eenheid en differensiasie kan vind wat Canlis via Calvyn identifiseer. Dit gee aanduidings van hoe die visie op die Triniteit en die verbondsgemeenskap rigtinggewend kan wees om leiding te gee oor die wyse waarop Suid-Afrika 'n gemeenskap (eenheid) van gemeenskappe (verskeidenheid) kan wees waarin met gemeenskap sowel as 'n gemeenskap (eenheid) van gemeenskappe nóg fusie, nóg vervreemding, nóg selfveragting, nog panteïsme, bedoel word.

Verder is daar ook 'n verband wat getrek kan word tussen gemeenskapsopvattings in die klassieke tradisie wat met 'n sin vir die permanente dinge gepaard gaan, en die klassieke

6.Die belydenis van Belhar maak wel ruimte daarvoor dat taal en kultuur deur die versoening in Christus geleenthede tot wedersydse diens en verryking binne die een sigbare volk van God is, maar die probleem met die erkenning van verskeidenheid in die Belhar belydenis is dat dit' $n$ opvatting van eenheid en verskeidenheid voorstaan wat sterk vanuit die individualisme geformuleer word. Die verskeidenheid word wat sterk vanuit die individualisme geformuleer word. Die verskeidenheid word implisiet as ' $n$ verskeidenheid individue hanteer. Daarom is daar nie werklik ruimte vir die gedagte aan ' $n$ gedifferensieerde eenheid van groepe nie. Dat die herskepping by die skepping aansluit en ook kultuurgroepe groter as die individu reinig en heilig, en dat opvattings van eenheid en verskeidenheid ook op hierdie vlak werksaam is, kan op hierdie wyse nie waardeer word nie. Goosen se kritiek is op die gebrek aa hierdie soort gedifferensieerde eenheid gerig. Vir verdere voorspraak vir 'n benadering wat nie soseer teen Belhar wil staan nie, maar anderkant die belydenis wil tree, vergelyk Bosman en Swanepoel (2014) in hierdie verband. 
leerstelling oor die enkelvoudigiheid (simplicitas) van God. In albei gevalle word ten onregte statiese en eentonige, koue en onpersoonlike voorstellings hiervan gemaak, veral in 'n postmoderne konteks. Die Christelike apologeet, G.K. Chesterton ([1908] 2009:64-65), het egter reeds lankal voortreflik daarop gewys dat die herhalende en standvastige aard van permanente dinge nie oor statiese toestande gaan nie, maar eerder oor lewenskragtigheid wat besonder sterk en oorvloedig aanwesig is en wat daarom permanensie of, in hedendaagse terme, volhoubaarheid tot gevolg het. Op treffende wyse merk Chesterton daarop dat ons juis daarom kan stel dat ons Vader jonger as ons is, omdat sy jeugdige, dog standvastige lewenskragtigheid, nie ophou nie. ${ }^{7}$ Dit gaan daarom nie oor monotone herhaling nie, maar eerder oor dramatiese encore, sê Chesterton ([1908] 2009:64-65).

Hierdie toepassing van standvastige permanensie wat verankerde rus en vrede in gemeenskappe tot gevolg het, kan direk met die enkelvoudigheid (simplicitas) van God in verband gebring word. Juis omdat God aan niks gebrek het nie en altyd dieselfde is, verander sy liefde nie en is daar geen einde aan sy geregtigheid of barmhartigheid nie. Dit bied juis die moontlikheid van diep en egte emosie - negatief by die goddelose, maar ook vol lig en lof by God se kinders. In laasgenoemde geval, hang dit ook saam met geborgenheid, geloof, hoop en liefde (vgl. Renihan, 2015). 'n Ander gerekende figuur, die reeds genoemde Thomas Weinandy (2000), toon verder treffend aan dat ook die leer van God se impassibilitas beslis nie as emosieloos of star begryp hoef te word nie. Weinandy (2000:viii) se hele benadering is daarop gemik om aan te toon dat die klassieke verstaan van God Bybels gesproke meer outentiek was, histories meer akkuraat, filosofies meer oortuigend, teologies meer oorredend en selfs emosioneel meer bevredigend.

Dit is dus duidelik dat daar diep begronde rekenskap in die klassieke teïsme opgesluit lê en dat daar wel by bepaalde beklemtonings van die sogenaamde renaissance aangesluit sou kon word, maar slegs wanneer dit duidelik word dat kosbare skatte nie weggegooi word nie en dat die klem op die relasionele meer as tendensieus is. Dit beteken ook dat daar ondersoek ingestel kan word of Ralph Smith met onbedoelde vorms van triteïsme rekening gehou het. Ook Horton se differensiasie tussen die eienskappe van God en die unieke eienskappe van elke Persoon van die Drie-eenheid sal duidelike verantwoording hieroor moet aflê. Dit beteken egter ook dat Horton (2011) se opmerkings oor Moltmann se sosiale trinitarisme met erns bejeën sal word. Dolezal (2017:loc. 2306 van 3485) merk in verband met Moltmann se waardering van perigorese op dat die klassieke beredenering hieroor die enkelvoudigheid van God juis veronderstel en dat perigorese, losgemaak hiervan, ook tot 'n eksotiese vorm van triteïsme kan lei. Dit is die tipe ondersoeke wat verdere aandag vra. Canlis (2010:loc. 3974 van 3982) se

7.Luister in hierdie verband ook gerus na die digwerk van Pous Johannes Paulus oor $l a$ tua semplicità wat in 'n pragtige bekende lied getoonset is, en wat deur Josh Groban en Placido Domingo gesing word en op YouTube gehoor kan word, tesame met ' $n$ en Placido Domingo gesing word en op YouTube gehoor kan word, tesame met' $n$
vertaling daarvan. In Afrikaans klink die koor ongeveer soos volg: 'Ek dink aan vertaling daarvan. In Afrikaans klink die koor ongeveer soos volg: 'Ek
daardie dag wat so vol sal wees van verwondering vir u enkelvoudigheid.' voorspraak vir 'n outentieke weergawe van die relasionele is daarom belangrik en haar voorstel dat Calvyn en Irenaeus se weergawe van koinonia die tipe ontologie bied wat selfs anderkant dié van die Radikale Ortodoksie leiding kan bied, is die moeite werd om verder na te vors.

Die omvang van die derde golf van bydraes oor die Triniteit vereis daarom 'n deurdagte nagaan van die diep gesetelde begrondings wat in die klassieke teïsme opgesluit lê, alvorens daar reformerend hierop voortgebou word. Dit vereis inderwaarheid 'n hele groep teoloë uit die reformatoriese tradisie wat hulleself pertinent met die sentimente van herwinningsteologie vereenselwig. Die tradisie van teologie aan Potchefstroom is ' $n$ besonder aangewese plek hiervoor wanneer die geskiedenis in ag geneem word. Dit sou inleidend reeds 'n hele konferensie vir genoemde teoloë kon reël om in mekaar se bloedstroom te kom - 'n konferensie wat oor meer as een dag hieraan aandag skenk en wat deurtastend, sistematies en bewustelik as alternatief op benaderings van die korrelasie-teologie aangebied word. Indien Walter Kasper se aangehaalde woorde waar is oor die geskiedenis van die moderne denke wat parallel loop met pogings om die leer van die Triniteit te herdefinieer, behoort hierdie voorstel gewig te dra by die vierings van die 150ste bestaansjaar van opleiding in die reformatoriese teologie. Laat ons dan toetree en op die rug van die derde golf verder stuur.

\section{Erkenning Mededingende belange}

Die outeur verklaar dat daar geen finansiële of persoonlike verbintenis is met enige party wat hom nadelig kon beïnvloed in die skryf van hierdie artikel nie.

\section{Outeursbydrae}

C.A.S. was die enigste outeur betrokke by die skryf van die artikel.

\section{Etiese oorwegings}

Hierdie artikel volg alle etiese standaarde vir navorsing.

\section{Befondsing}

Hierdie navorsing het geen spesifieke toekenning ontvang van enige befondsingsagentskap in die openbare, kommersiële of nie-winsgewende sektore.

\section{Data beskikbaarheidsverklaring}

Die deel van data is nie van toepassing op hierdie artikel nie, aangesien geen nuwe data in hierdie studie geskep of ontleed is nie.

\section{Vrywaring}

Die sienings en menings wat in hierdie artikel uitgedruk word, is dié van die outeur en weerspieël nie noodwendig 
die amptelike beleid of posisie van enige geaffilieerde agentskap van die outeur nie.

\section{Literatuurverwysings}

Alcade, D., 2019, Cosmology without God? The problematic theology inherent in modern cosmology, Cascade, Eugene, OR.

Allen, M. \& Swain, S.R., 2015, Reformed catholicity: The promise of retrieval for theology and biblical interpretation, Baker Academic, Grand Rapids, MI.

Bosman, J. \& Swanepoel, C.A., 2014, Die Belhar debat: Anderkant Belhar, besoek 14 November 2019, by https://maroelamedia.co.za/debat/meningsvormers/diebelhar-debat-anderkant-belhar/.

Canlis, J., 2010, Calvin's Ladder: A spiritual theology of ascent and ascension, Eerdmans, Grand Rapids, MI.

Chesterton, G.K., [1908] 2009, Orthodoxy, Moody Bible Institute, Chicago, IL.

Conradie, E.M., 2019, 'South African discourse on the Triune God: Some reflections', HTS Teologiese Studies/Theological Studies 75(1), a5483. https://doi.org/10.4102/ hts.v75i1.5483

Dolezal, J.E., 2017, All that is in God: Evangelical theology and the challenge of classical Christian theism, Reformation Heritage, Grand Rapids, MI.

Goosen, D., 2015, Belhar: die rustelose spook, besoek 14 November 2019, by https://npvanwyklouw.org.za/belhar-die-rustelose-spook/.

Goosen, D.P., 2007, Die nihilisme: notas oor ons tyd, Dainfern, Praag.

Grenz, S.J., 2004, Rediscovering the Triune God: The Trinity in contemporary theology, Fortress, Minneapolis, MN.

Hanby, M., 2003, Augustine and modernity, Routledge, London.

Holmes, S.R., 2012, The quest for the Trinity: The doctrine of God in Scripture, history and Modernity, IVP Academic, Downers Grove, IL.

Horton, M.C., 2006, God of promise: Introducing covenant theology, Baker, Grand Rapids MI.

Horton, M.C., 2011, The Christian Faith: A systematic theology for pilgrim's on the way, Zondervan, Grand Rapids, MI

Kasper, W., 2012., The God of Jesus Christ, Bloomsbury, London.

Kärkkäinen, V., 2007, The Trinity: Global perspectives, Westminster John Knox Press, Louisville, KY.

Letham, R., 2004, The Holy Trinity: In Scripture, history, theology, and worship, P\&R, Phillipsburg, NJ.

Milbank, J., [1990] 2006, Theology and social theory, Blackwell, Oxford.

Milbank, J. \& Pickstock, C., 2002, Truth in Aquinas, Routledge, London.
Molnar, P.D., 2014, 'Classical Trinity: Catholic perspective', in J.S. Sexton \& S.N. Gundry (eds.) Two views on the doctrine of the Trinity, pp. 95-132, Zondervan, Grand Rapids, MI.

Peterson, D.A., 2013, 'Book reviews: Stephen R. Holmes. The quest for the Trinity: The doctrine of God in Scripture, history and modernity', in Journal of Cultural Encounters, vol. 9, no.1, 102-108.

Peterson, D.A., 2016, 'Sacred Monster: On the fears of some recent trinitarianism', Journal of Cultural Encounters 12(1), 3-36.

Renihan, S., 2015, God without passions: A primer, RBAP, Palmdale, CA.

Sanders, F., 2004, The image of the immanent Trinity: Rahner's rule and the theologica interpretation of scripture, Peter Lang Inc, New York, NY.

Sanders, F., 2010, The deep things of God: How the Trinity changes everything, Crossway, Wheaton, IL.

Sanders, F., 2016, The Triune God, Zondervan, Grand Rapids, MI.

Smith, J.K.A., 2004, Introducing radical orthodoxy: Mapping a post-secular theology, Baker Academic, Grand Rapids, MI.

Smith, R.A., 2002, Paradox and truth: Rethinking Van Til on the Trinity, Canon, Moscow.

Smith, R.A., 2003, Eternal covenant: How the Trinity reshapes covenant theology, Canon, Moscow, ID.

Smith, R.A., 2004, Trinity and reality: An introduction to the Christian faith, Canon, Moscow.

Strauss, D.F.M., 1991, 'Hoe kan ons wetenskaplik oor God praat?', TCW 27(2), 23-43.

Strauss, D.F.M., 2002, 'Wetenskap', in E.J. Van Niekerk \& H.J. Hayes (reds.), Reformerend die millenium in: Ons Calvinistiese erfenis en roeping, pp. 23-43, $\mathrm{VCHO}$, Bloemfontein.

Vanhoozer, K.J., 2014, 'Three (or more) ways of triangulating theology: On the very idea of a Trinitarian system', in T.D.J Harris \& J.S. Sexton (eds.), Revisioning, renewing, rediscovering the Triune center: Essays in honor of Stanley J. Grenz, pp. 31-58, Cascade, Eugene, OR.

Van Wyk Louw, N.P., 1986, Versamelde prosa, vol. 1, Tafelberg, Kaapstad.

Venter, R., 2006, 'Space, trinity and city: A theological exploration', Acta Theologica 26(1), 201-224.

Venter, R., 2010, 'Doing Trinitarian theology: Primary references to God and imagination', In die Skriflig 44(3 \& 4), a162. https://doi.org/10.4102/ids.v44i3/4.162

Venter, R., 2011, 'Speaking God today: The adventures of a rediscovered trinitarian grammar', Inaugural Lecture, University of the Free State, Bloemfontein.

Venter, R., 2012, 'Triniteit en etiek: Van 'n relasionele God tot ' $n$ etiek van die Ander', In die Skriflig 46(1), a52. http://dx.doi.org/10.4102/ids.v46i1.52

Venter, R., 2019, 'Taking stock of the Trinitarian renaissance: What have we learnt?', HTS Teologiese Studies/Theological Studies 75(1), a5407. https://doi.org/10.4102/ hts.v75i1.5407

Weinandy, T.G., 2000, Does God suffer? Notre Dame Press, Notre Dame, IN. 